\title{
STUDIES ON REVERSION OF INDUCED PLANT WEIGHT CHANGES IN FLAX BY OUTCROSSING
}

\author{
ALAN DURRANT \\ Department of Agricultural Botany, University College of Wales, Aberystwyth, Wales
}

Received 6. x. $7^{1}$

\section{INTRODUCTION}

THE large (L) and small (S) genotrophs induced from the intermediate plastic (Pl) genotroph of the flax variety Stormont Cirrus (Durrant, 1962a) have remained stable in their inheritance of plant weight for more than 12 generations. Different environments in which they have been grown have not induced any further heritable changes, L remaining up to six times the size of $\mathrm{S}$, the variation in the magnitude of the differences from year to year being due to genotype $\times$ environment interactions only (Durrant, 1971). Changes in amount of nuclear DNA, on the other hand, normally induced at the same time as the plant weight difference (Evans, Durrant and Rees, 1966; Evans, 1968), can be partly reversed by growing $L$ and $S$ at a lower temperature which narrows the 16 per cent. difference to 5 per cent. within two generations (Durrant and Jones, 1971). There is no accompanying change in plant weight.

There is, however, the possibility that reversion in the plant weights of $\mathrm{L}$ and $\mathrm{S}$ to the $\mathrm{Pl}$ plant weight might be brought about by changing the genetic background through outcrossing to other varieties. The $F_{1}$ of crosses between $L$ and $S$ is genetically unstable and the increased $F_{1}$ variation is inherited among the $\mathrm{F}_{2}$ families (Durrant, 1962b). Although this instability may arise only where apparently equal and opposite induced changes are brought together in the $\mathrm{L} / \mathrm{S}$ heterozygote, $\mathrm{L}$ and $\mathrm{S}$ could separately be sensitive to the introduction of other genetic backgrounds and perhaps revert completely.

If $L$ and $S$ are crossed separately to another variety, $K$, in an ideal, additive situation, if no reversion has occurred, the $\mathrm{L}$ crosses in subsequent generations should be larger than the $S$ crosses by an amount equal to half the difference between $\mathrm{L}$ and $\mathrm{S}$. If the $\mathrm{L}$ crosses are no different to $\mathrm{S}$ crosses there are four explanations; the genetic factors determining $\mathrm{L}$ and $\mathrm{S}$, (i) revert to $\mathrm{Pl}$ factors, or at least they are no longer different, (ii) are recessive to factors from $K$, (iii) interact with factors from $K$, or (iv) interact with the environment and $\mathrm{K}$. In the first case the genetic difference between $\mathrm{L}$ and $\mathrm{S}$ is eliminated, in the other three the difference remains but it is not shown in the phenotype. Separation may be possible in further generations, in other crosses or from other observations.

Allied to this question of reversion on outcrossing $\mathrm{L}$ and $\mathrm{S}$ is the one of response to selection. Would the eventual plant weight of a line selected for high, or low, plant weight be greater in a cross of $\mathrm{L}$ with $\mathrm{K}$ than the corresponding selection in a cross of $\mathrm{S}$ with $\mathrm{K}$, i.e., would the breeder have committed himself at the outset to a particular product depending on whether he had used L or S? Results obtained from crosses with five other varieties, 
and selection over four generations in crosses with a sixth, suggest that it depends upon the variety used for outcrossing.

\section{Selection FRom Grosses of L AND S With the LINSEED VARIETY ROYAL}

Crosses were made between $\mathrm{L}$ plants, between $\mathrm{S}$ plants, between plants of the linseed variety Royal (R), and reciprocally between $L$ and $R$ ( $L R$ crosses), and $S$ and $R$ ( $S R$ crosses). Generations $F_{1}$ to $F_{6}$ inclusive were grown in years 1963 to 1969 respectively, omitting 1968. There were no significant reciprocal differences, and the same set of $\mathrm{R}$ plants was used for crosses with $\mathrm{L}$ and $\mathrm{S}$ so that there were essentially five groups of plants, $\mathrm{L}, \mathrm{S}$, $\mathrm{R}, \mathrm{LR}$ and $\mathrm{SR}$, which were treated the same with regard to plant culture, selection and number of plants grown. Two sets of five $F_{1}$ plants were grown (in the case of LR and SR these were the two reciprocals) in each of the groups and the largest and smallest plant selected in each set. Two $\mathrm{F}_{2}$ plots of five plants each were grown from each of the four selected $F_{1}$ plants, a total of 120 plants for the five groups. Four high and four low selection lines were begun with the selection of the four largest and four smallest plants from among each group of $40 \mathrm{~F}_{2}$ plants. Two $\mathrm{F}_{3}$ plots of five plants each were grown from each of the eight selected $\mathrm{F}_{2}$ plants giving $80 \mathrm{~F}_{3}$ plants for each group, 400 plants altogether. The largest, or smallest, plant was selected from among the 10 plants of the two $\mathrm{F}_{3}$ plots of each selection line and the procedure repeated up to the 6 th generation. Each year the plants were grown out of doors from sowing, and partial reversion of the induced changes in amount of nuclear DNA occurred in L and S (Durrant and Jones, 1971), but plant weight was unaffected.

Table 1 gives the mean plant weights from $F_{2}$ to $F_{6}$ of the mean of the four high selection lines, the mean of the four low selection lines, and the overall mean of the high and low selection lines combined, for each of the five groups L, S, R, LR, SR. Table 2 gives $t$ values (single tail) for each of the five groups from $\mathrm{F}_{3}$ to $\mathrm{F}_{6}$. The first $t$ value in each case tests the mean difference between the high and low selection lines against the variation between the four high selection lines and between the four selection lines $($ d.f. $=6)$. The second $t$ value tests the mean difference between the high and low selection lines against the individual field plot error $($ d.f. $=7$ ) calculated separately for each generation of each group. Selection has had no effect in $\mathrm{L}, \mathrm{S}$ or $\mathrm{R}$ and the means of their high and low selection lines combined have been used hereon as estimates of the three parental values. Significant differences appear between the high and low selection lines of LR and SR, but the significance is higher in LR.

The mean of the combined high and low selection lines of LR, and of SR, have been used for obtaining for each generation the various estimates, (1) to (6), shown at the foot of table 1. If the response to high and low selection were symmetrical with no gene interaction the potence ratios (the deviation of the cross from the midparent value divided by half the parental difference) of LR and SR should decrease by a half each generation. The potence ratio of $L R$ (1) is negative and erratic over generations. The potence ratio of $\mathrm{SR}(2)$ is positive in the $\mathrm{F}_{2}$ but becomes increasingly negative, the SR mean moving away from $\mathrm{R}$ towards $\mathrm{S}$. Although the mean plant weight of all plants grown in each year (3) varies four-fold over the years due to seasonal 
TABLE 1

Mean plant weights $(g)$, from $F_{2}$ to $F_{6}$, of high and low selection lines of $L, S, R$, $L R$ and $S R$

\begin{tabular}{|c|c|c|c|c|c|}
\hline Selection & $F_{2}$ & $\mathrm{~F}_{3}$ & $\mathrm{~F}_{4}$ & $F_{5}$ & $\mathrm{~F}_{6}$ \\
\hline High & $43 \cdot 0$ & $78 \cdot 4$ & $57 \cdot 5$ & $63 \cdot 7$ & $15 \cdot 4$ \\
\hline Low & $47 \cdot 0$ & $68 \cdot 1$ & $63 \cdot 7$ & $73 \cdot 7$ & $18 \cdot 0$ \\
\hline Mean & $45 \cdot 0$ & $73 \cdot 2$ & $60 \cdot 6$ & $68 \cdot 7$ & $16 \cdot 7$ \\
\hline High & $7 \cdot 3$ & $24 \cdot 0$ & $20 \cdot 0$ & $35 \cdot 7$ & $4 \cdot 5$ \\
\hline Low & $12 \cdot 0$ & $27 \cdot 1$ & $17 \cdot 7$ & $31 \cdot 4$ & $4 \cdot 6$ \\
\hline Mean & $9 \cdot 6$ & $25 \cdot 5$ & $18 \cdot 8$ & $33 \cdot 5$ & $4 \cdot 5$ \\
\hline High & $62 \cdot 0$ & $120 \cdot 2$ & $97 \cdot 1$ & 106.9 & $43 \cdot 4$ \\
\hline Low & $62 \cdot 0$ & $143 \cdot 7$ & $95 \cdot 7$ & $98 \cdot 0$ & $46 \cdot 6$ \\
\hline Mean & $62 \cdot 0$ & $131 \cdot 9$ & $96 \cdot 4$ & $102 \cdot 4$ & $45 \cdot 0$ \\
\hline High & $46 \cdot 7$ & $127 \cdot 0$ & $91 \cdot 4$ & $93 \cdot 7$ & $43 \cdot 1$ \\
\hline Low & $53 \cdot 5$ & $74 \cdot 7$ & $42 \cdot 9$ & $69 \cdot 0$ & $15 \cdot 1$ \\
\hline Mean & $50 \cdot 1$ & $100 \cdot 8$ & $67 \cdot 1$ & $81 \cdot 3$ & $29 \cdot 1$ \\
\hline High & $43 \cdot 5$ & $87 \cdot 2$ & $51 \cdot 4$ & $72 \cdot 2$ & $17 \cdot 4$ \\
\hline Low & $40 \cdot 7$ & $69 \cdot 7$ & $36 \cdot 2$ & $45 \cdot 9$ & $8 \cdot 7$ \\
\hline Mean & $42 \cdot 1$ & $78 \cdot 4$ & $43 \cdot 8$ & $59 \cdot 0$ & $13 \cdot 0$ \\
\hline
\end{tabular}

\begin{tabular}{|c|c|c|c|c|c|c|}
\hline $\begin{array}{l}\text { Item } \\
\text { No. }\end{array}$ & Item & & & & & \\
\hline 1 & $\begin{array}{l}\text { Potence ratio of } \\
\text { LR }\end{array}$ & -0.40 & -0.06 & -0.64 & $-0 \cdot 25$ & $-0 \cdot 12$ \\
\hline 2 & $\begin{array}{l}\text { Potence ratio of } \\
\text { SR }\end{array}$ & $0 \cdot 24$ & -0.01 & -0.36 & -0.26 & -0.56 \\
\hline 3 & $\begin{array}{l}\text { Mean plant } \\
\text { weight }\end{array}$ & $41 \cdot 8$ & $82 \cdot 0$ & $56 \cdot 3$ & $69 \cdot 0$ & $21 \cdot 7$ \\
\hline 4 & $\frac{1}{2}(\mathrm{~L}-\mathrm{S})$ & $17 \cdot 7$ & $23 \cdot 8$ & $20 \cdot 9$ & $17 \cdot 6$ & $6 \cdot 1$ \\
\hline 5 & LR - SR & $8 \cdot 0$ & $22 \cdot 4$ & $23 \cdot 3$ & $22 \cdot 3$ & $16 \cdot 1$ \\
\hline 6 & $\frac{\mathrm{LR}-\mathrm{SR}}{\frac{1}{2}(\mathrm{~L}-\mathrm{S})}$ & 0.45 & 0.94 & $1 \cdot 11$ & $1 \cdot 27$ & $2 \cdot 64$ \\
\hline
\end{tabular}

\section{TABLE 2}

$t$ values testing mean differences between high and low selection lines against (1st entry) differences between the four high selection lines and between the four low selection lines, and against (2nd entry) the field plot error

\begin{tabular}{|c|c|c|c|c|}
\hline & $\mathrm{F}_{3}$ & $\mathrm{~F}_{4}$ & $\mathrm{~F}_{5}$ & $F_{6}$ \\
\hline L & $\begin{array}{l}1 \cdot 37 \\
0 \cdot 80\end{array}$ & $\begin{array}{l}0.50 \\
0.61\end{array}$ & $\begin{array}{l}1 \cdot 34 \\
1 \cdot 39\end{array}$ & $\begin{array}{l}2 \cdot 03 \\
2 \cdot 06\end{array}$ \\
\hline S & $\begin{array}{l}1 \cdot 18 \\
0.59\end{array}$ & $\begin{array}{l}1.43 \\
0.99\end{array}$ & $\begin{array}{l}1 \cdot 27 \\
1 \cdot 20\end{array}$ & $\begin{array}{l}0.22 \\
0 \cdot 18\end{array}$ \\
\hline $\mathrm{R}$ & $\begin{array}{l}1 \cdot 34 \\
0.85\end{array}$ & $\begin{array}{l}0 \cdot 10 \\
0 \cdot 15\end{array}$ & $\begin{array}{l}0.56 \\
1 \cdot 39\end{array}$ & $\begin{array}{l}0.44 \\
0.37\end{array}$ \\
\hline LR & $\begin{array}{l}1 \cdot 97 * \\
3 \cdot 12 * *\end{array}$ & $\begin{array}{l}3 \cdot 25^{* *} \\
3 \cdot 04^{* *}\end{array}$ & $\begin{array}{l}1 \cdot 50 \\
5 \cdot 56 * *\end{array}$ & $\begin{array}{l}3 \cdot 19 * * \\
4 \cdot 10 * *\end{array}$ \\
\hline SR & $\begin{array}{l}1.22 \\
1.53\end{array}$ & $\begin{array}{l}1 \cdot 45 \\
2 \cdot 17^{*}\end{array}$ & $\begin{array}{l}2 \cdot 40 * \\
4 \cdot 32 * *\end{array}$ & $\begin{array}{l}2 \cdot 29 * \\
1.99 *\end{array}$ \\
\hline
\end{tabular}

Significance levels (single tail); * 5 per cent.; ** 1 per cent.

differences the potence ratio is not correlated with it. The differences between $\mathrm{L}$ and $\mathrm{S}$ (4) are, as would be expected, strongly correlated with the mean plant weights but the differences between LR and SR (5) are only 
slightly correlated. With symmetrical response and no gene interaction the difference LR-SR divided by half the L-S difference should be equal to one in each generation, but (6) shows that there is a steady, and significant $\left(P<5\right.$ per cent.) increase from $F_{2}$ to $F_{6}$, from 0.45 to $2 \cdot 64$. By the 6 th generation there is a bigger difference between LR and SR than between $\mathrm{L}$ and $\mathrm{S}$, when the difference should be only half as big as that between $\mathrm{L}$ and $\mathrm{S}$. Instead of any evidence of reversion of $\mathrm{LR}$ and $\mathrm{SR}$ there is increasing divergence over generations.

The increase in the difference between LR and SR is due to the asymmetric response of the high and low selection lines of SR. S is recessive in the $\mathrm{F}_{2}$ and selection is likely to be more efficient in a downward direction, but the rapid decline in the low selection lines is accompanied by little or no progress in the high selection lines. In the $\mathrm{F}_{4}$ the high selection lines are below, and in the $F_{6}$ well below, the midparent value of $S$ and $R$. It may be that, with regard to the genetic factors which differ between $\mathrm{L}$ and $\mathrm{S}$, those possessed by $\mathrm{S}$ are similar to those of $\mathrm{R}$, which could restrict the selection potential of SR compared with LR, but this would not give an asymmetric response to selection. There are four explanations: (l) inefficient selection in SR due to large interactions with the environment; (ii) interaction of the high selection line with the environment, particularly in $\mathrm{F}_{4}$ and $F_{6}$ generations; (iii) gene interaction within $S R$; (iv) factors in $S$ induce changes in the hybrid nucleus of SR in the direction of $\mathrm{S}$.

The principal conclusions are, first, the induced changes in plant weight of $\mathrm{L}$ and $\mathrm{S}$ show no sign of reverting on outcrossing to the linseed variety Royal, and continue to exist in a different genetic background up to the 6 th generation and, second, selection for high plant weight in crosses of $\mathrm{L}$ with Royal gives higher plant weights than selection in crosses of $\mathrm{S}$ with Royal.

\section{Grosses between L, S AND Pl AND Five other VARIEties}

Crosses were made in 1968 between the three genotrophs of Stormont Cirrus, $\mathrm{L}, \mathrm{S}$ and $\mathrm{Pl}$ and five other varieties, $\mathrm{K}_{1}$ to $\mathrm{K}_{5}$ shown in table $3(\mathrm{a})$.

$$
\text { TABLE 3(a) }
$$

Flax and linseed varieties crossed with $L$, $S$ and $P l$ of the variety Stormont Cirrus

$\begin{array}{ll}\text { Lyral Monarch } & \mathrm{K}_{1} \\ \text { Stormont Motley } & \mathrm{K}_{2} \\ \text { Percello } & \mathrm{K}_{3} \\ \text { Hollandia } & \mathrm{K}_{4} \\ \text { Dakota } & \mathrm{K}_{5}\end{array}$

Dakota is a linseed variety, the others are flax. Crosses were also made between plants within each genotroph, and within each $\mathrm{K}$ variety to maintain the parents under the same conditions as the other crosses, giving altogether for each $\mathrm{K}$ variety the group of ten crosses listed in table 3(b). $\mathrm{Pl} \times \mathrm{Pl}, \mathrm{L} \times \mathrm{L}$ and $\mathrm{S} \times \mathrm{S}$ occurred in all five $\mathrm{K}$ groups but separate crosses were made for each group. Six $F_{1}$ plants were grown in 1969 from each cross, a total of 300 plants. The $F_{2}$ was grown in 1970 in five blocks in the field, one block for each of the $\mathrm{K}$ groups. There were four replicates in each 
block, each replicate containing ten plots of six plants each. The ten crosses of the $\mathrm{K}$ set assigned to any one block of four replicates were randomised over the ten plots in each replicate. This gives a total of 1200 plants for the five $\mathrm{K}$ sets. The design gives comparisons between the ten crosses of each $\mathrm{K}$ group; direct comparisons between the overall means of the five $\mathrm{K}$ groups are confounded with soil differences.

TABLE ( 3 b)

The ten crosses made for each $K$ variety

$\left.\begin{array}{ll}\mathrm{L} \times \mathrm{L} \\ \mathrm{S} \times \mathrm{S} \\ \mathrm{P} 1 \times \mathrm{P} 1 \\ \mathrm{~K} \times \mathrm{K} \\ \mathrm{L} \times \mathrm{K} \\ \mathrm{K} \times \mathrm{L} \\ \left.\begin{array}{l}\mathrm{S} \times \mathrm{K} \\ \mathrm{K} \times \mathrm{S} \\ \mathrm{P} 1 \times \mathrm{K} \\ \mathrm{K} \times \mathrm{Pl}\end{array}\right\}\end{array}\right\} \begin{aligned} & \mathrm{LK} \\ & \mathrm{SK} \\ & \end{aligned}$

Separate analyses of variance of the five sets of $\mathrm{K}$ crosses gave significant differences between the ten crosses in each case, but no significant reciprocal differences. Table 4 gives the mean plant weights of parents and reciprocal means, with the midparent values entered in brackets beneath the corresponding reciprocal means. Values for $\mathrm{L}, \mathrm{S}$ and $\mathrm{Pl}$ appear in each set. $\mathrm{L}$ is two to four times the size of $\mathrm{S}$ with $\mathrm{Pl}$ approximately intermediate.

TABLE 4

Mean plant weights $(\mathrm{g}$.) of parents and reciprocal means. The midparent values are in brackets under the corresponding reciprocal means

\begin{tabular}{|c|c|c|c|c|c|}
\hline & $\begin{array}{c}\text { Lyral } \\
\text { Monarch }\end{array}$ & $\begin{array}{c}\text { Stormont } \\
\text { Motley }\end{array}$ & Percello & Hollandia & Dakota \\
\hline $\mathbf{L}$ & $22 \cdot 2$ & $29 \cdot 8$ & $48 \cdot 2$ & $41 \cdot 1$ & $19 \cdot 6$ \\
\hline $\bar{S}$ & $8 \cdot 0$ & $9 \cdot 9$ & $14 \cdot 2$ & $22 \cdot 2$ & $4 \cdot 8$ \\
\hline P1 & $14 \cdot 7$ & $20 \cdot 7$ & $34 \cdot 1$ & 33.1 & $10 \cdot 6$ \\
\hline $\mathrm{K}$ & $12 \cdot 4$ & $10 \cdot 0$ & $42 \cdot 0$ & $24 \cdot 0$ & 23.4 \\
\hline LK & $14 \cdot 1$ & $\begin{array}{l}14 \cdot 8 \\
(19 \cdot 9)\end{array}$ & $\begin{array}{c}44 \cdot 1 \\
(45.1\end{array}$ & $\begin{array}{c}42 \cdot 7 \\
(32.6\end{array}$ & $\begin{array}{l}19 \cdot 5 \\
(1.5\end{array}$ \\
\hline SK & $\begin{array}{c}11 \cdot 7 \\
(10 \cdot 2)\end{array}$ & $\begin{array}{l}10.3 \\
(9.9)\end{array}$ & $\begin{array}{c}35 \cdot 6 \\
(28 \cdot 1)\end{array}$ & $\begin{array}{c}(32 \cdot 0) \\
29 \cdot 3 \\
(23 \cdot 1)\end{array}$ & $\begin{array}{c}(21 \cdot 0) \\
17 \cdot 1 \\
(14 \cdot 1)\end{array}$ \\
\hline PIK & $\begin{array}{c}14 \cdot 5 \\
(13 \cdot 6)\end{array}$ & $\begin{array}{c}14.5 \\
(15 \cdot 3)\end{array}$ & $\begin{array}{c}40 \cdot 8 \\
(38 \cdot 1)\end{array}$ & $\begin{array}{c}35 \cdot 7 \\
(28 \cdot 6)\end{array}$ & $\begin{array}{c}19 \cdot 4 \\
(17 \cdot 0)\end{array}$ \\
\hline
\end{tabular}

The three genotroph values vary considerably between the sets reflecting the large soil variation between the blocks.

Assuming no gene interaction, genetic differences between $\mathrm{L}, \mathrm{S}, \mathrm{Pl}$ and variety $\mathrm{K}_{i}(i=1,2, \ldots, 5)$ can be split into two parts. One consists of those genetic factors $\left(k_{i}\right)$ which $\mathrm{L}, \mathrm{S}$ and $\mathrm{Pl}$ have in common (i.e., are characteristic of the variety Stormont Cirrus, $\mathrm{Pl}$ ) but which are different from those in $\mathrm{K}_{\boldsymbol{i}}$. The other contains those genetic factors in $\mathrm{L}$ and $\mathrm{S}(1, \mathrm{~s})$ which differ from those in Pl. Each may be further split into additive and dominance components (table 5) using the $d$ (additive effect) and $h$ (dominance effect) notation of Mather (1949). The values are given in table 6 for all $\mathrm{K}$ groups. 
In the table of additive effects, table 6(a), the column means are the overall deviations in mean plant weight of $\mathrm{L}, \mathrm{S}$ and $\mathrm{Pl}$ from the mean plant weight of all $\mathrm{K}$ varieties. The $\mathrm{Pl}$ genotroph, the original variety of Stormont Cirrus from which $\mathrm{L}$ and $\mathrm{S}$ were induced, has a plant weight which is practically the same as the mean plant weight of all $\mathrm{K}$ varieties. $\mathrm{Pl}$ also has a plant weight almost exactly intermediate in weight between $\mathrm{L}$ and $\mathrm{S}$.

TABLE 5
Half parental differences $(\Sigma \mathrm{d})$ and $F_{2}$ devia- tions from the midparent values $\left(\frac{1}{2} \Sigma \mathrm{h}\right)$ obtained on outcrossing $L, S$ and $P l$ to variety $K_{i}$. See text for components

Half parental differences

$$
\begin{aligned}
\frac{1}{2}\left(\mathrm{~L}-\mathrm{K}_{i}\right) & =\Sigma d_{k i}+\Sigma d_{l} \\
\frac{1}{2}\left(\mathrm{Pl}-\mathrm{K}_{i}\right) & =\Sigma d_{k i} \\
\frac{1}{2}\left(\mathrm{~S}-\mathrm{K}_{i}\right) & =\Sigma d_{k i}+\Sigma d_{s}
\end{aligned}
$$

$\mathrm{F}_{2}$ deviations from midparent values

$$
\begin{aligned}
\mathrm{LK}_{i}-\frac{1}{2}\left(\mathrm{~L}+\mathrm{K}_{i}\right) & =\frac{1}{2} \sum h_{k i}+\frac{1}{2} \Sigma h_{i} \\
\mathrm{PlK}_{i}-\frac{1}{2}\left(\mathrm{Pl}+\mathrm{K}_{i}\right) & =\frac{1}{2} \sum h_{k i} \\
\mathrm{SK}_{i}-\frac{1}{2}\left(\mathrm{~S}+\mathrm{K}_{i}\right) & =\frac{1}{2} \Sigma h_{k i}+\frac{1}{2} \Sigma h_{s}
\end{aligned}
$$

Each row mean gives the deviation of the mean plant weight of the three genotrophs combined from the mean plant weight of the $\mathrm{K}$ variety in that row. Comparisons between these row means give a better assessment of the relative mean plant weights of the $\mathrm{K}$ varieties, (i.e., Dakota, the linseed variety, is the largest, and Stormont Motley the smallest) than the values in table 4 which contain block differences due to soil heterogeneity, since in

\section{TABLE $6(a)$}

Half parental differences (g.) calculated from mean plant weights, between $L, S$ and $P l$ and each of the five varieties

\begin{tabular}{lrrrr} 
& L & \multicolumn{1}{c}{ Pl } & \multicolumn{1}{c}{ S } & Mean \\
Lyral Monarch & 4.91 & $1 \cdot 19$ & $-2 \cdot 19$ & $1 \cdot 30$ \\
Stormont Motley & $9 \cdot 89$ & 5.35 & $-0 \cdot 09$ & $5 \cdot 05$ \\
Percello & 3.06 & -3.96 & $-14 \cdot 09$ & $-5 \cdot 00$ \\
Hollandia & $8 \cdot 01$ & $4 \cdot 49$ & -0.96 & $4 \cdot 01$ \\
Dakota & -1.90 & -6.40 & -9.27 & $-5 \cdot 86$ \\
Mean & 4.89 & 0.13 & $-5 \cdot 32$ & -
\end{tabular}

table 6(a) they are each measured against the three genotrophs occurring in each block. The comparisons may still be blurred, however, by variety $\times$ block interactions.

The $\mathrm{F}_{2}$ deviations from their midparent values are given in table $6(\mathrm{~b})$, a positive value indicating $F_{2}>$ midparent, a negative value, $F_{2}<$ midparent. Dominance of $\mathrm{K}$ variety or genotroph is obtained by comparing tables 6(a) and $6(\mathrm{~b})$; like signs show that the genotroph is dominant, unlike signs that the $\mathrm{K}$ variety is dominant.

The column means of table $6(\mathrm{~b})$ are the overall mean $\mathrm{F}_{2}$ deviations from their midparent values averaged over all $\mathrm{K}$ varieties for $\mathrm{L}, \mathrm{S}$ and $\mathrm{Pl}$ respectively. The row means are the overall mean $F_{2}$ deviations from their mid- 
parent values, for each $\mathrm{K}$ variety, averaged over the three genotrophs. In the absence of reversion, gene interaction or certain dominance relations, the three deviations given by $\mathrm{L}, \mathrm{S}$ and $\mathrm{Pl}$ in any row, or in the column means, should be identical. On the other hand, the five deviations given by the five $\mathrm{K}$ varieties in any one column, or in the row means, are not expected to be equal, the distinction being that in the genotrophs, $\mathrm{L}$ and $\mathrm{S}$ are assumed to be unidirectionally induced changes in plus and minus directions respectively from $\mathrm{Pl}$ superimposed upon a common genetic background, whereas in the $\mathrm{K}$ varieties the genes for large and small plant weights are distributed among them.

Although the variation between the $\mathrm{K}$ dominance deviations is the greater, e.g., a range of 10 between the row means of table $6(\mathrm{~b})$ there is substantial variation between the genotroph deviations as well, and a range of 3.5 in the column means. The row means show that the greatest mean deviation occurs when Hollandia is crossed with the genotrophs, and comparisons with the row means of table 6 (a) show that all $\mathrm{K}$ varieties are dominant to the genotrophs except Hollandia which is recessive. In the column means Pl here also has an approximately intermediate value between $\mathrm{L}$ and $\mathrm{S} ; \mathrm{S}$ has the highest mean deviation and is strongly recessive in crosses with the $\mathrm{K}$ varieties. These are generalisations, averaging over the genotrophs, and

\section{TABLE 6(b)}

\begin{tabular}{|c|c|c|c|c|}
\hline & L & PI & S & Mean \\
\hline Lyral Monarch & $-3 \cdot 20$ & 0.94 & 0.99 & $-0 \cdot 42$ \\
\hline Stormont Motley & $-4 \cdot 75$ & -0.89 & 0.44 & -1.72 \\
\hline Percello & -0.97 & $2 \cdot 72$ & $7 \cdot 41$ & 3.05 \\
\hline Hollandia & $11 \cdot 60$ & $7 \cdot 09$ & $6 \cdot 14$ & $8 \cdot 27$ \\
\hline Dakota & -1.96 & $2 \cdot 47$ & 3.04 & $1 \cdot 18$ \\
\hline Mean & 0.15 & $2 \cdot 47$ & $3 \cdot 60$ & - \\
\hline
\end{tabular}

over the $\mathrm{K}$ varieties. Before comparing them individually an analysis of variance of the $\frac{1}{2} \sum h$ values of $\mathrm{L}, \mathrm{S}$ and $\mathrm{Pl}$ was made for each set of $\mathrm{K}$ crosses using, for each set, its own error obtained from replication in the field. The error variation of Percello was significantly larger than any of the others, so this variety was omitted from a combined analysis of variance on the $\frac{1}{2} \sum h$ values of the twelve combinations given by the three genotrophs and the remaining four $\mathrm{K}$ varieties, using their combined error (table 7 ).

Differences in the deviations between the four sets of $K$ crosses are highly significant as expected, item (1) in table 7. The differences between the three genotrophs split into $\mathrm{L}-\mathrm{S}$ and $\mathrm{L}+\mathrm{S}-2 \mathrm{Pl}$, items (2) and (3), are not significant implying that overall the induced changes do not revert, nor interact, on outcrossing, but the $(\mathrm{L}-\mathrm{S}) / \mathrm{K}$ interaction item (4) has a probability just on 5 per cent. $\mathrm{Pl}$ is approximately intermediate between $\mathrm{L}$ and $\mathrm{S}$, items (3) and (5), and when the sums of squares of these two items, together with the considerably higher one of $\mathrm{L}-\mathrm{S}$ (2) are combined with error, the $(\mathrm{L}-\mathrm{S}) / \mathrm{K}$ interaction is significant at the 5 per cent. level. Therefore factors determining the induced changes partly revert or, interact, when crossed with some of the $K$ varieties. 
The pattern of interaction is easily picked out in fig. 1, which also contains Percello excluded from the analysis of variance because of its different error variation. In this diagram where the $\mathrm{L}, \mathrm{S}$ and $\mathrm{Pl} \frac{1}{2} \sum h$ values are

\section{TABLE 7}

Analysis of variance of $F_{2}$ deviations from midparent values in table $6(b)$ with the outcrosses to Percello omitted

\begin{tabular}{|c|c|c|}
\hline Item & d.f. & $\begin{array}{l}\text { Mean } \\
\text { square }\end{array}$ \\
\hline (1) Varietal crosses (K) & 3 & $235 \cdot 29 * * *$ \\
\hline 2) $\mathrm{L}-\mathrm{S}$ & 1 & $36 \cdot 23$ \\
\hline 3) $\mathrm{L}+\mathrm{S}-2 \mathrm{Pl}$ & 1 & 7.23 \\
\hline (4) $(\mathrm{L}-\mathrm{S}) \times \mathrm{K}$ & 3 & $51.47 *$ \\
\hline (5) $(\mathrm{L}+\mathrm{S}-2 \mathrm{Pl}) \times \mathrm{K}$ & 3 & $8 \cdot 54$ \\
\hline (6) Error & 24 & $17 \cdot 43$ \\
\hline (7) $(\mathrm{L}-\mathrm{S}) \times\left(\mathrm{K}_{1}+\mathrm{K}_{2}+\mathrm{K}_{8}-3 \mathrm{~K}_{4}\right)$ & 1 & $153 \cdot 65 * *$ \\
\hline (8) $(\mathrm{L}-\mathrm{S}) \times\left(\mathrm{K}_{1}, \mathrm{~K}\right.$ & 2 & $0 \cdot 77$ \\
\hline
\end{tabular}

Significance levels; * 5 per cent.; ** 1 per cent.; *** $0 \cdot 1$ per cent.

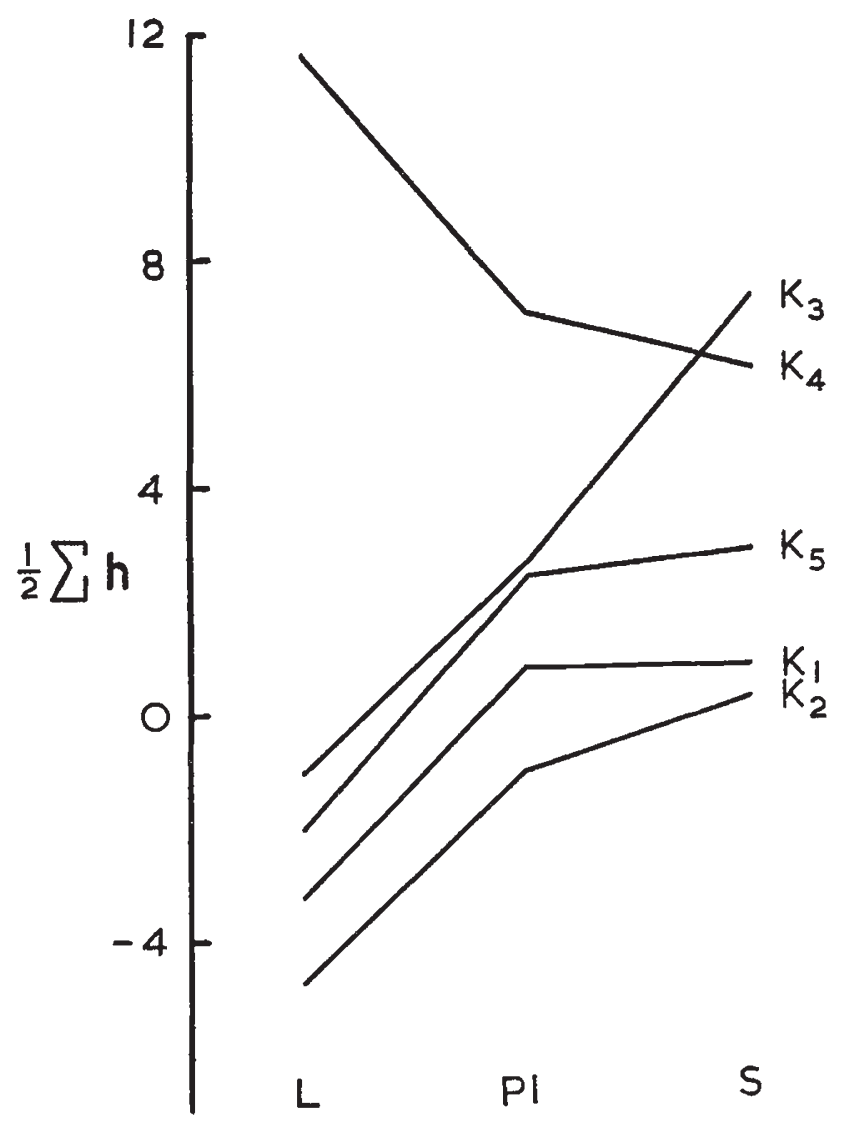

Frg. 1.-Deviations from midparent values in the $\mathrm{F}_{2}$ of $\mathrm{L}, \mathrm{Pl}$ and $\mathrm{S}$ outcrosses with each of the five $K$ varieties. $K_{4}$ (Hollandia) shows divergence (see text), the others apparent reversion. 
plotted for each $\mathrm{K}$ variety, Hollandia is different from the others. Zero slope means neither reversion not interaction of the genotrophs. A positive slope means reversion, or an interaction or dominance relation which has the same phenotypic effect; a negative slope means increased divergence or an interaction or dominance relation having the same phenotypic effect. In the analysis of variance (table 7) the specific interaction of Hollandia versus Dakota, Lyral Monarch and Stormont Motley with $\mathrm{L}-\mathrm{S}$ is tested and is highly significant, item (7). Since the latter three varieties and Percello are also homogeneous in fig. 1 they have been combined in fig. 2 to show

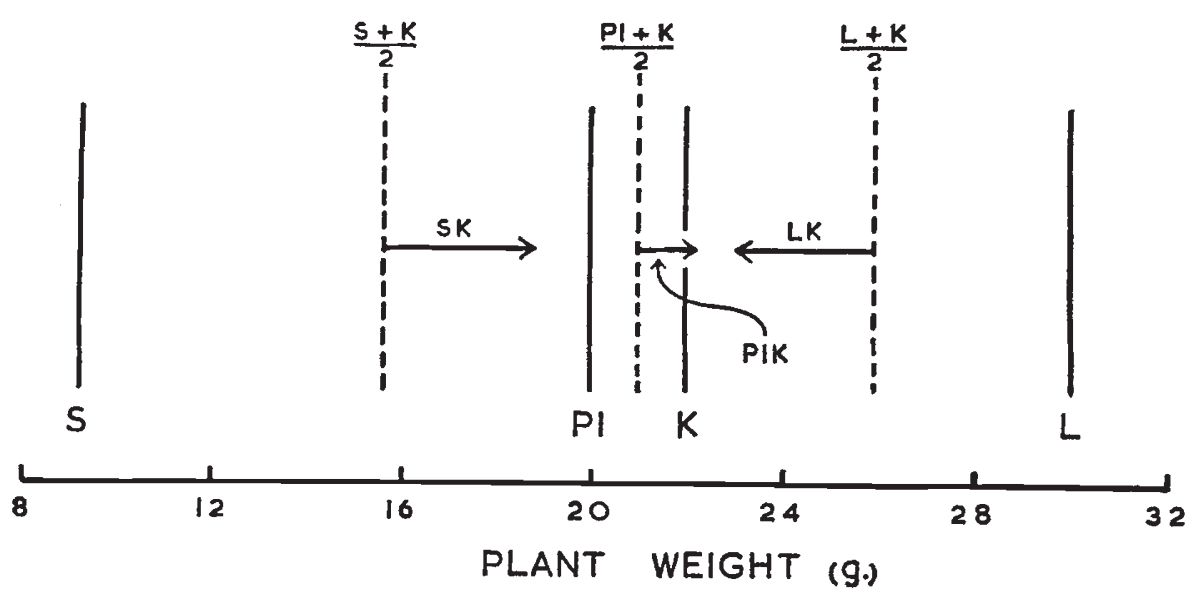

FIG. 2. - Mean plant weights after summing over all sets of crosses involving $K_{1}, K_{2}, K_{3}$ and $\mathrm{K}_{8}$. Values of $\mathrm{L}, \mathrm{S}, \mathrm{Pl}$ and $\mathrm{K}$ are shown by unbroken lines and the mean $\mathrm{F}_{2}$ deviations from the midparent values are marked by the arrows. The SK, PIK and LK means have an overall mean (21.4) almost equal to the $\mathrm{Pl}$ and $\mathrm{K}$ midparent value $(21 \cdot 1)$.

their average $\mathrm{LK}, \mathrm{SK}$ and PIK $\mathrm{F}_{2}$ values with respect to the parent and midparent values. The three $\mathrm{F}_{2}$ means converge towards a point which is situated between $\mathrm{Pl}$ and the mean $\mathrm{K}$ value, as though $\mathrm{L}$ and $\mathrm{S}$ contributions in their respective crosses with the $\mathrm{K}$ varieties revert towards the $\mathrm{Pl}$ contribution in its crosses with the $K$ varieties. If it is in fact reversion the four varieties possess factors which are capable of breaking down the hitherto stable induced changes. Hollandia plotted on a similar graph would have shown divergence of the $\mathrm{F}_{2}$ values, although the divergence itself is not significant, compared with their midparent values and therefore this variety behaves in this experiment in a similar way to Royal, described in the previous section. It follows that whereas Hollandia must be recessive, the other $\mathrm{K}$ varieties must be dominant, in crosses with the genogrophs, as concluded from the earlier appraisal of the data.

\section{Discussion}

The six varieties which were crossed with the genotrophs separate into two groups. In the first group are Royal and Hollandia where there is no evidence of reversion, the $\mathrm{L}$ and $\mathrm{S}$ induced changes becoming, if anything, more pronounced. In the second group are Percello, Lyral Monarch, Stormont Motley and Dakota. Here partial reversion of the $L$ and $S$ 
induced changes appears to have occurred in the $F_{2}$ of their crosses with $L$ and $\mathrm{S}$. If this apparent reversion is not reversion at all but gene interaction, then the same pattern of gene interaction occurs in all four crosses, and in the different environments of the field blocks ( $\mathrm{L}, \mathrm{S}$ and $\mathrm{Pl}$ in table 4). For example, the $\mathrm{L}$ and $\mathrm{S}$ factors may have a strong effect on plant weight in the $\mathrm{L}$ and $\mathrm{S}$ genotrophs but relatively little effect in the hybrids. Different soil conditions in the Hollandia block may have given a relatively large S plant weight (table 4) so that the differences between the varieties in fig. 1 could be a reflection of soil differences between field blocks. Expressed in dominance terms, $\mathrm{K}$ alleles are dominant to $\mathrm{L}$ and $\mathrm{S}$ alleles. This is an unual pattern of dominance since $K$ is intermediate in plant weight. These interpretations can be checked in the $\mathrm{F}_{3}$. If it is true reversion, presumably it will be progressive; if only apparent reversion, it will tend to disappear with increasing homozygosity.

Royal and Dakota are linseed varieties, the rest are flax, hence the two groups do not separate flax from linseed, nor is it likely that there is a separation into plastic and non-plastic types, i.e., varieties in which heritable changes can and cannot be induced by the environment. The $\mathrm{L}$ and $\mathrm{S}$ induced changes must be firmly fixed if they can survive the heterogeneous background and selection over several generations following outcrossing to a different type of plant like Royal. On the other hand, if reversion has occurred in the $\mathrm{F}_{2}$ of outcrosses to the varieties in the second group the ease with which it occurs suggests that these varieties contain a specific factor(s) capable of breaking down the induced change. This factor could, of course, be at the same (compound) locus as the induced changes themselves in which case the interaction is not unlike paramutation; or the four varieties may contain controlling elements while Royal and Hollandia do not.

Reversal may be mediated in flax, at least partly, by different events than those determining genetic instability. In plant weight, $\mathrm{F}_{1}$ genetic instability is dependent upon the heterozygous $\mathrm{L} / \mathrm{S}$ and has not been observed in crosses between $\mathrm{L}$ or $\mathrm{S}$ with other varieties, though it may occur in some environments. Genetic instability of the Hairy-hairless (H-h) capsule character (Durrant and Nicholas, 1970) appears to be almost entirely dependent upon the heterozygote $\mathrm{H} / \mathrm{h}$ when $\mathrm{L}$ and $\mathrm{S}$ are crossed, but the amount of instability is subject to the genotrophic background. Whether a comparable amount of instability occurs at the $h$ locus on outcrossing to other varieties has to be determined. By contrast, partial reversion of the induced changes in amount of nuclear DNA in L and S can be obtained by growing these genotrophs, homozygous, at lower temperatures, and of course the initial heritable changes are induced in the homozygous $\mathrm{PI}$ genotroph by the environment.

Whether or not reversion would occur had L and S been crossed to Pl is a different problem, because here the environment of the parental plastic plants, and of the progeny, must be assessed with regard to the possibility than any changes may be due to the transmission of changes induced in P1 to the progeny of the crosses. There is also evidence (Durrant, 1971) that $\mathrm{L}$ and $\mathrm{S}$, though stable, are themselves capable in some environments of transmitting environmentally induced changes to the $F_{1}$ and later generations when they are crossed to $\mathrm{Pl}$ grown in a control environment. It may be that the six varieties used, or at least those of the second group, would show plasticity if they were examined in a range of environments, and that the same arguments should apply to these. 


\section{Summary}

1. The large (L) and small (S) genotrophs, induced by growing plants of the flax variety Stormont Cirrus in different environments, have remained stable in plant weight for over 12 generations. Since environments have no further effect on their plant weights they were each outcrossed to other varieties to determine whether a different genetic background would break down, or reverse, the induced changes.

2. In outcrosses to a linseed variety Royal the induced changes remained and were easily detected in the 6th generation of the cross despite the heterogeneous background and selection.

3. In a breeding programme, selection for high plant weight in crosses of $\mathrm{L}$ with varieties behaving like Royal would give higher plant weights than would selection carried out in crosses using $\mathrm{S}$ instead of $\mathrm{L}$.

4. Apparent partial reversions of the induced changes occurred in the $F_{2}$ of four out of five other varieties to which $L$ and $S$ were outcrossed. If they are not true partial reversions they must be due to patterns of dominance or gene interaction and gene/environment interaction. If they are true partial reversions the four varieties may each contain a specific factor(s) capable of breaking down, or reversing, the $\mathrm{L}$ and $\mathrm{S}$ induced changes.

\section{REFERENCES}

DURRANT, A. 1962a. The environmental induction of heritable change in Linum. Heredity, $17,27-61$.

DURRANT, A. 1962b. Induction, reversion and epitrophism of flax genotrophs. Nature, 204, 1302-1304.

DURRANT, A. 1971. The induction and growth of flax genotrophs. Heredity. In the press. DURRANT, A., AND NICHOLAS, D. B. 1970. An unstable gene in flax. Heredity, 25, 513-527. DURRANT, A., AND JONES, T. W. A. 1971. Reversion of induced changes in amount of nuclear

DNA in Linum. Heredity, 27, 431-439.

EVANs, G. M. 1968. Nuclear changes in flax. Heredity, 23, 25-38.

EVANS, G. M., DURRANT, A., AND REES, H. 1966. Associated nuclear changes in the induction of flax genotrophs. Nature, 212, 697-699.

mather, K. 1949. Biometrical Genetics. Methuen \& Co. Ltd, London. 